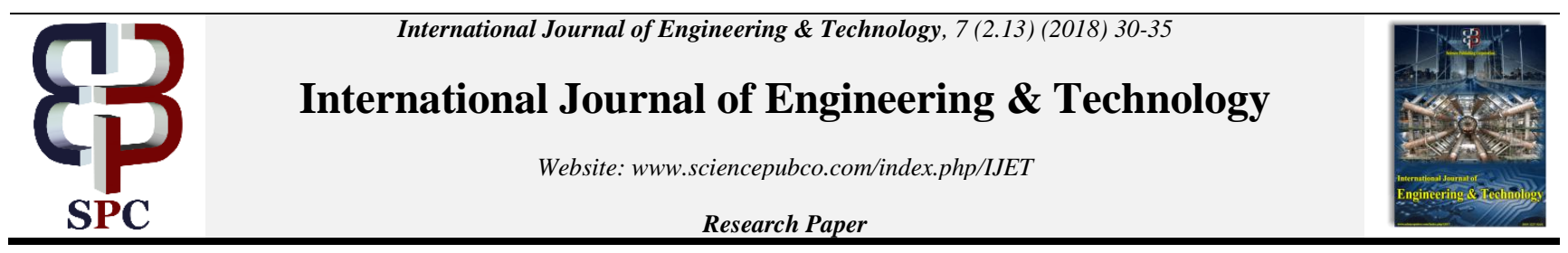

\title{
Vocational training in sport and recreation micro-enterprises as an education project
}

\author{
Svetlana V. Komleva*, Tatyana V. Andryukhina, Evgeniya V. Ketrish, Nataliya V. Tretyakova, \\ Irina P. Korotkikh, Tatyana S. Okrimenk \\ Russian State Vocational Pedagogical University, Ekaterinburg, Russia \\ *Corresponding author E-mail: svkomleva@ list.ru
}

\begin{abstract}
This study appears urgent due to the need to create new jobs in the sport and recreation sector and to update the existing approach to vocational training in a micro-enterprise. This paper proposes an education project as a form of vocational training in such conditions. The authors aim to comprehend the current issues of pedagogical design for the transfer of experience within a micro-enterprise of the sport and recreation sector and to determine the conditions for effective educational interaction of micro-enterprise employees. This problem is addressed with a combination of the systematic approach and activity-based learning. This makes it possible to present the process of pedagogical design of vocational training in the conditions of a micro-enterprise as systematic activity of individuals in developing the professional competencies of a sport and recreation worker. The authors used theoretical and empirical methods. The theoretical methods were analysis of the psychological, pedagogical, sociological, scientific-methodological and specialized literature on the studied problem; the systematic approach to the definition of the problem and the formation of the research terminology; and analysis of the legal acts. The empirical methods were pedagogical observation; study and generalization of pedagogical experience; pedagogical design; questioning; conversation; interview; performance analysis; and expert evaluation method and integration of expert opinions.
\end{abstract}

Keywords: Vocational Training; Micro-Enterprise; Pedagogical Design; Sport and Recreation Sector; Educational Interaction

\section{Introduction}

At present, it is obvious that getting vocational education in youth does not guarantee employment and demand on the labor market throughout the work life. The lack of physical, moral and time resources for adults with dependent children, mortgage payments or other financial obligations draws their attention to vocational training in the form of self-education and on-the-job training. Learning basic skills during professional activity gives social and financial protection to the working individuals. Employees of sport and recreation micro-enterprises (an experienced professional who needs additional human resources, on the one hand, and an employee who does not have sufficient level of professional competence, on the other hand) enter the educational process to achieve certain goals. The study of the accumulated knowledge on the educational relations of employees in the conditions of company operation made it possible to identify a number of contradictions that hinder its development in theoretical, and, first of all, in practical terms. These contradictions are caused by the growing needs of individuals, society and economy in improving the efficiency and quality of vocational training of micro-enterprise workers. Another reason is the opportunity for educational interaction in the sport and recreation microenterprises to meet such needs in on-the-job training, given that the organizational and pedagogical conditions, ensuring the efficiency of such interaction, may be insufficiently developed.

These contradictions and related problems occur due to insufficient study of on-the-job training in modern socio-economic conditions. The authors put forward the assumption that the solution to problems and contradictions in the educational interaction of sport and recreation micro-enterprise employees can be found in the theoretical substantiation and development of organizational and pedagogical conditions that may explain and design this interaction.

\section{Methods and methodological framework}

\subsection{Research methodology}

The methodological and theoretical basis of the research was formed by the major works on the fundamentals of educational methodology and methods [1], [2] studies of personally oriented vocational education [3], [4], and works in the field of pedagogical design [5] The study was carried out on the basis of the regulatory and legal requirements of the current legislation in the field of vocational education and in the field of small business development.

\subsection{Research methods}

The authors used the following methods:

The theoretical methods were analysis of thepsychological, pedagogical, sociological, scientific-methodological and specialized literature on the studied problem; the systematic approach to the definition of the problem and the formation of the research terminology; and analysis of the legal acts.

The empirical methods were pedagogical observation; study and generalization of pedagogical experience; pedagogical design; questioning; conversation; interview; performance analysis; and expert evaluation method and integration of expert opinions. 


\subsection{Experimental basis of the study}

Micro-enterprises of the sport and recreation sector in Sverdlovsk Oblast, Russia, formed the experimental base of this research; 379 participants were involved in the study.

\section{Results}

\subsection{Educational interaction of employees in conditions of a sport and recreation micro-enterprise}

The educational interaction of employees consists in developing the competencies of a worker who performs professional functions in the real business conditions of a company [6], [7], [8]. Training and development of employees is one of the most important factors for the successful functioning of any organization [9]. In addition to the direct effect on the financial results by raising the level of professional skills, the investments in professional development contribute to the creation of a favorable organizational climate, increase personnel motivation and loyalty to the organization, and ensure continuity in management. Learning is natural for a human; nevertheless, it requires conscious efforts, since training is not a passive activity. A trainee should actively work in the learning process and make conscious efforts to the acquisition of knowledge. The success of training depends on the degree of difficulty of the perceived material: if too easy or extremely difficult, the material reduces the efficiency of perception. Only when the trainee makes sufficient efforts, the learning material is acquired completely.

Practical focus appears the most significant in the vocation training for sport and recreation workers. The theoretical foundations are important for the perception and acquisition of practical skills. New knowledge should be related to the life and previous experience of the trainee, and the closer this connection is, the more successful is the knowledge acquisition.

Any learning process has five essential elements. The first two elements - diversity and clarity - are related to the actions of the instructor. Other two elements - involvement and success - are related to the activities of the trainee. The last element - similarity - describes the relationship between the instructor and the trainee. Trainee's involvement into the learning process is a necessary condition for the successful perception of information. Learning cannot happen unless the trainee takes an active part in the educational process. In fact, the more interactive the learning process is, the more successful the trainee will be [10].Therefore, the situation of success in training is necessary. The instructor should be sure that his trainee can successfully acquire what is taught. If an adult finds themselves in a situation of failure in the training activity, they may find reasons for quitting the training. On the contrary, the situation of success is a powerful stimulus to continue education.

Hence the learning process is organized by the means of pedagogical design. The educational interaction of employees is designed as an individual training program that pursues the achievable learning goals, specific for each trainee.

In social psychology and pedagogy, interaction of humans is viewed as the process of impact on each other, in which each action is perceived both as the previous action and the expected outcome from the other action. In the educational literature, the concept of interaction is interpreted differently, and researchers emphasize various aspects of this fairly broad concept. Any interaction supposes the presence of at least two participants, and represents actions with a pronounced focus on another person.

Interaction is not only a direct exchange of information, but also an indirect exchange of meanings, a form of communication that is much broader than interpretation of messages. Interaction is objective, and it has a purpose or cause that is external towards the interacting subjects. Interaction is available for observation, it is essentic. The main characteristics of interaction are the mutual cognition, mutual understanding, mutual relations, mutual actions, and mutual influence. Each of these characteristics has its own content, and their integrated implementation in interaction ensures its efficiency.
The integrative characteristics of interaction include the workability and compatibility. Compatibility is manifested in the satisfaction of the subjects of interaction, in emotional support and comfort. Workability is characterized by consistency in actions, which ensures their success in terms of quantity, quality, speed, optimal coordination of mutual assistance of the interacting parties.

In terms of focus, the interaction can be direct or indirect; in terms of controllability, it can be controlled, semi-controlled and uncontrolled, accidental or intentional; in terms of duration, it can be short-term or long-term; in terms of efficiency, the interaction can be productive and counter-productive. The interaction types are cooperation, dialog (verbal and non-verbal), agreement, custody, suppression, indifference, confrontation, and conflict.

Each of the interaction types affects the psychological state of interacting subjects: productive interaction brings satisfaction, counter-productive interaction is accompanied by negative emotions of fear, panic, anxiety, hostility, and secrecy. The main goal of interaction is the development of personality of the interacting subjects and the realization of their capabilities.

Usually, the interaction is linked to a specific situation and expresses the participants' intentions. Interaction as cooperation takes the form of collaboration - a partnership of individuals aimed at solving a common problem or achieving personally significant goals of each participant, when the activity of all participants in the interaction is necessary to achieve the result. Interaction as competition is expressed in the course of hidden or exhibited rivalry for the possession of values, when the goal of one participant in the interaction is achieved through the failure of other participants. Productive interaction can turn into competitive or conflicting in case of the collision of competing parties.

Interaction in educational activity is similar to pedagogical interaction, where the personal contact of the instructor and the trainee is aimed at mutual changes in their behavior, actions and attitudes. It is characterized by a feedback, i.e. the presence of a response. There may be no response, but it is still assumed. It is important for the trainee to know how they perform the assigned task; the trainee needs an external evaluation of their skill from the instructor. It is also important for the instructor to know the degree of assimilation of the translated knowledge. The evaluation can have a form of scoring, rating, verbal and symbolic appraisal. In any form, it serves as a feedback. In the educational interaction of adults, the cooperation and partnership are the preferred types that minimize the possible transition to a conflict, yet cannot exclude it.

Interaction in professional activity depends on the nature of the work, the position of the employees, the level of experience and practical skills, and many other factors. In the interaction of colleagues, cooperation and competition can co-exist, if these forms of interaction do not lead to counter-productive conflicts.

While studying this problem, [11], [12], the authors found it possible to specify the concept of educational interaction in the conditions of a micro-enterprise. It can be defined as the coordinated mutual productive actions of two or more employees, aimed at solving educational (acquisition of professional competencies) and professional (company operation) tasks in the process of collaborative labor activity using the internal resources of the micro-enterprise (Figure 1).

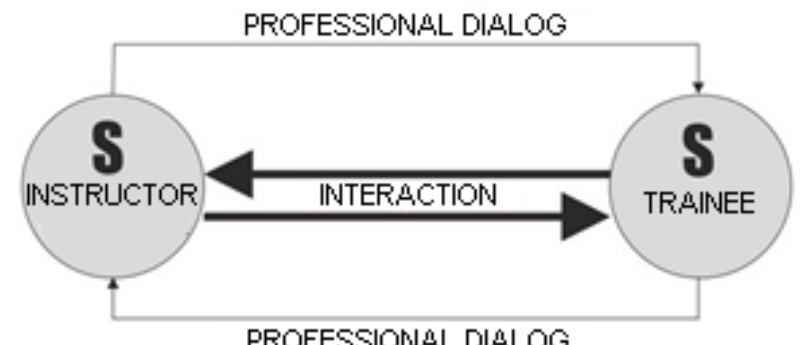

Fig. 1: M Odel of the Educational and Professional Interaction of Employees in the Conditions of a Micro-Enterprise. 
The educational interaction of a more experienced employee with a less experienced employee differs from corporate training since the trainee is given additional rights and responsibilities simultaneously with the training. At the same time, the learning process is initiated by the trainee; additional knowledge is not imposed and there is no external motivation for learning. In this case, the training goes in parallel with the process of expanding the responsibilities of the trained employee. Thus, there appears the pedagogical situation of free professional communication and partnership between the instructor and the trainee (subject-to-subject relations). It turns pedagogical assistance into a system of means of trainees' self-determination in various professional activities under supervision of more experienced co-workers.

Educational interaction in the professional environment is focused on the interchange of practical experience, support and development of the employees for the purpose of their career or personal growth. Sometimes it is used to achieve strategic business goals. The content of educational interaction is rather broad. It can be determined by the urgent needs in the development of the competence of employees. Also, it is an economically efficient method of professional development in a small enterprise. The expenses on creating and maintaining an efficient system of educational interaction are smaller than the cost of traditional methods of employee training. Moreover, the experience passed on to the trainee may be unique. The instructor also benefits from the interaction through the feedback. The educational interaction favorably affects the moral and psychological climate in the organization. The atmosphere of support in the team simplifies adaptation of new personnel, while the instructors realize their need to be involved in the life of the company. All this improves the flexibility of each employee by expanding their professional competence.

It should be noted that it is not entirely correct to interpret the educational interaction as a procedure for adapting new employees. The educational interaction solves of a narrow range of strictly professional tasks, while adaptation implies the inclusion into the corporate system. The duration of adaptation and educational interaction of employees are indirectly related. There are the areas of activity in which the skill development takes a few weeks, but there are others that require long-term or permanent learning. Ideally, the educational interaction of employees should be uninterrupted in a specific period of time, ensuring the continuous development of workers. During this period of time, the more experienced and qualified employee hands over to the trainee the knowledge and skills that are required for effective performance of professional duties. In other words, the educational interaction of employees is aimed at the development of applied professional competencies. In a microenterprise that does not have an educational center, such form of professional support is justified and valuable from the humanist point of view.

\subsection{Entrepreneurship in sport and recreation sector}

The specific features of a micro-enterprise are a small number of personnel and the lack of not only a training center, but also a human resources specialist. This function, like many other managerial functions, is often performed by the head of the enterprise. In modern socio-economic conditions, self-employment through running a small enterprise is one of the ways to solve the problem of unemployment and an opportunity to self-actualize in professional activity on a new level. Russian society becomes increasingly aware that entrepreneurship is one of the most important factors in the formation and development of the market economy. The creation of the State Committee for the Support and Development of Small and Medium-Sized Businesses and the adoption of the Federal Law "On state support of small and medium-sized businesses in the Russian Federation" confirm this fact. The Russian Constitution regulates the free use of abilities and assets for entrepreneurial activity as an independent activity, carried out at one's own risk and directed to the systematic receipt of profits from the use of property, the sale of goods, the performance of work, or the provision of services.
Individual entrepreneurship is one of the simplest forms of business activity, the success or failure of which directly depends on the personal and professional qualities of the entrepreneur. By legal definition, an individual entrepreneur is an individual who is registered in accordance with the established procedure and carries out business activity without forming a legal entity. However, in order to organize and successfully develop a business, the entrepreneur must possess a certain set of traits that allow them to carry out professional activities independently [13].

The professionally important psychological characteristics of entrepreneurs include such personal traits as the need for independence, readiness to take risks, determination, energy, optimism, self-confidence, the need for domination, focus at problem solving, ability to learn, adapt and change according to the situation .For many individual entrepreneurs, working activity is not only a business, but a means of self actualization, the meaning of life, and a legacy to their children. An entrepreneur is a new type of a worker, smoothly combining the high qualifications of an employee, the abilities of a good business manager and the qualities of a morally healthy personality. The owner, the manager, and the performer are rolled into one person. Today's Russian entrepreneurs are the first generation in their business activities. Devoid of a parental example, possibly brought up on other values, they must be naturally endowed with business qualities that allow them to be more assertive, emotionally stable, self-possessed and motivated to achieve. [14] note that successful entrepreneurs are less susceptible to following the group and social norms; they are endowed with richer imagination, flexibility and independence; they have a well developed abstract thinking and the ability to learn. Such people are emotionally stable, active and courageous; they strive to dominate, renounce authorities, are difficult to deceive, have creative imagination and often behave incomprehensibly to others. In conflict situations, they compromise, but do not adapt to the opponent. Thus, a successful individual entrepreneur is likely to have a personal autonomy, that is, the ability to adequately use and develop their own potential abilities in professional activities and interaction with the external social space.

On the path of economic development, the entrepreneur becomes an employer and organizes workplaces at their enterprise. Therefore, the entrepreneur faces the problem of vocational training of potential employees. The labor market offers specialists trained according to the advanced development program in employment centers [15].Usually, such workers have experience in another profession, theoretical knowledge and minimal practical skills in the newly acquired profession, hence they need on-the-job training.

The head of a micro-enterprise may conclude an employment contract with young specialists - graduates of vocational schools. However, the most successful graduates tend to continue their education or seek employment in large enterprises with the possibility of career growth and social benefits, which is sometime unavailable at a micro-enterprise. Consequently, young specialists with an insufficient level of professional training are often the only workers to enter labor relations with an individual entrepreneur.

Despite significant level of unemployment, micro-enterprises lack workers and the employer hires personnel who does not have any vocational education but is capable of on-the-job-training. An entrepreneur and a potential employee voluntarily enter the vocational training process, for they are motivated to achieve a goal in a relatively short time given the reasonable organization of experience transfer and professional development process [16].

\subsection{Efficient implementation of education project in con- ditions of a sport and recreation micro-enterprise}

The modern type of organization of educational activities is a design and technology type [17], [18]. It supposes that the productive activity of an individual is divided into separate cycles, which are called projects.

Project design, as a special kind of mental activity, is based on the natural ability of a human (in contrast to an animal) to mentally create models of the future and to turn them into reality. Latin word 'prōiectus' (prominent, protruding) implies a prototype of some 
kind of activity. A purposeful action is carried out on the basis of the prototype, kind of a project. Project design activity, in a strategic sense, is a step-by-step implementation of the image of the future, planning from the fundamentally new goal for organizing the activity, which is limited in terms and resources. Thus, the project may be defined as a pragmatic focus on the result, which is achieved through solving a practically or theoretically significant problem. The result of solving a practical problem is a specific product ready for consumption. When solving a theoretical problem, the result is a specific solution, designed in an information product. A person ceases to be the owner of an idea, renounces their own and private in order to get a chance to come across something else, to fill themselves with it, and to show it in his creative work.

According to its target, the project design may be classified into technical or engineering one (design of things) and social (creating models of social phenomena, new forms of social life). In social project design, pedagogical project design is singled out as a separate block. The main characteristic feature of a pedagogical project design lies in its focus not only on the object of design, but also on the subjects (participants) and on the process itself. In other words, pedagogical project design is a way of innovative transformation of pedagogical reality. It is based on the principles of predictability, step-by-step implementation, standardization, feedback, productivity, and cultural analogy.

The vocational on-the-job training may be presented in the form of an education project, which is based on the educational interaction of employees.

The project design algorithm in the education project development and implementation includes the following steps:

1) Identifying the need to develop an education project; definition of the expected result; formulation of the project objectives.

The analysis of employer's needs in training for the employees, the analysis of possibilities of micro-enterprises to satisfy the needs in vocational training of its employees, and the analysis of educational preferences of potential micro-enterprise employees help to identify the expected result of the project.

2) Setting goals for the implementation of the project objectives; identification of ideas, ways to achieve the goals and objectives; definition of the necessary activities to achieve the goal.

Goal setting is one of the most important steps of the project design. If the head of an enterprise fails to establish the purpose of the education project and to determine the specific tasks, any attempt to perform vocational training becomes spontaneous, and the investment in the project is risky.

3) Developing the project concept (an aggregate of fundamental ideas for teamwork); forecasting results (expected positive outcomes, possible risks, and methods of their mitigation).

The study developed and justified the structural and functional model of the educational interaction of the micro-enterprise workers. Its subject matter at this stage of the design would allow showing the entire mechanism of the education project implementation.

4) Determining the participants of the design activity during the design and kick-off of the project; team building and distributing the functions; defining the deadlines.

The education project leader is usually the head of a micro-enterprise. However, functions of the instructor can be performed by other qualified and experienced personnel. At this step of the project design, the trainee is included in the work as a full participant.

5) Structural planning; establishing the business contacts; selforganization of the education project participants; co-organization of patterns of collective management planning activity; contracting, commissioning of the control system. Activities involved in the education project are standardized and documented. The contract of apprenticeship or other form of local acts defines the rights and obligations of the parties.

6) Content development; organization of learning; communication and connection between participants.

At this step the participants may again lean on the developed structural and functional model, already having a specific content. Hence the organization of interaction between the education project participants is not spontaneous, the implementation of the planned volume of work does not require additional resources and time, and communication is productive and friendly.

7) Testing and experimental verification of the learning outcomes; evaluation and summing up the intermediate results; comparison of the achieved results with the objectives; socialization of

8) The design results (critical project review).

The achieved results are used in the professional activities, and may be presented within the micro-enterprise or anywhere else. After the successful completion of the education project, the trainee can confirm their qualification by passing a qualifying exam in the organization engaged in the educational activities.

9) Searching for additional funding sources to continue the project design activity.

Having received a positive learning result, the employer, who invested their resources into the education project, may think of other sources of funding, such as the provision of conditions for practical training or internship for students of educational organizations; receiving the state support in the Implementation of advanced training programs for redundant workers.

10) Capacity building (rescheduling); selecting technologies and their distribution; strengthening the structure of the project; expansion of social partnership; training for colleagues and partners.

A fully implemented education project is replicable. Although there may be some substantial alternations in case of changing the project participants or conditions. Having obtained experience in creating and implementing the education project, the head of an enterprise may broadcast it to colleagues and partners outside the enterprise, sharing experience and discussing issues using networking opportunities [19], [20]

Design, as a representation of the necessary actions for implementing the pedagogical plan, can be described as the aggregate of programming and planning, where programming is the creation of the program (the program itself is a set of necessary measures and actions to the achieve planned goals) and planning is developing a plan to achieve the goal, the project specification. The sesign implies a conscious and independent decision-making on the activities and responsibility for the selected options. Apart from the traditional organization of vocational training, where the instructor's part prevails, the project design activity is possible if all the training participants are included into the professional communication.

The implementation of the developed project requires certain conditions that are available or should be created. These conditions mean specially arranged external circumstances, without which the project cannot work. In practice, more than one condition is typically created for the project implementation. A set of interrelated conditions can ensure a certain attainable outcome of the project. To specify the conditions, one needs to identify external factors that significantly affect the implementation of the project and the level of success [21]. Management conditions, providing purposeful planning, organization, coordination, regulation and control over the process of educational interaction of employees may be defined as organizational condition. If the project has an educational focus, the organizational environment cannot be enough for its efficient implementation. It also requires the identification of specific pedagogical conditions as a set of pedagogical factors and specially created circumstances that affect the productivity of the educational process. The specification of the organizational and pedagogical conditions of the education project implementation (which is based on educational interaction of the micro-enterprise workers) takes into account several elements: firstly, the specificity of micro-enterprise environment; secondly, the individual characteristics of the interaction participants; thirdly, the uniqueness of informal teaching activities in the course of vocational on-the-job training. Identified organizational and pedagogical conditions provide opportunities for training and professional interaction of the employees to satisfy the needs of the individual micro-enterprises, the society and 
the economy in improvement of the efficiency of vocational training for workers of micro-enterprises.

At the final stage of the study, the authors compared the results of experimental stage of research on this problem; the results of the teaching process and professional interaction of the employees at the experimental companies; the descriptive assessment of the pedagogical project efficiency from the viewpoints of all participants of the experiment; and the results of comparative analysis of the teaching models for a micro-enterprise.

The analysis substantiates the efficiency of the proposed education project based on the subject-to-subject educational interaction of micro-enterprise employees in various business environments.
The summarized assessment (on a scale from one to five) of the implementation of developed organizational and pedagogical conditions for educational interaction of the micro-enterprise employees are presented in Table 1, where:

1) point - positive result is not achieved;

2) points - the lowest level of achieved result;

3) points - average level of achieved result;

4) points - sufficient level of achieves result;

5) points the highest level of achieved result

Table 1: The Implementation Results of the Organizational and Pedagogical Conditions for Educational Interaction of the Micro-Enterprise Employees

\begin{tabular}{|c|c|c|}
\hline Performance indicators & Assessment methods & Mark \\
\hline $\begin{array}{l}\text { Objective indicators of the } \\
\text { work }\end{array}$ & $\begin{array}{l}\text { Assessment of the following indicators: productivity, defects in work, the speed of the filling of } \\
\text { orders, increase in the number of new customers, increase in sales. }\end{array}$ & 4,0 \\
\hline Acquired knowledge and skills & Testing on the knowledge, assessment of the performance of specific tasks, speed of operations & 3,7 \\
\hline Changes in behavior & $\begin{array}{l}\text { Written or oral tests (e.g., changes in dealing with customers). Polls of co-workers, customers, } \\
\text { self-assessment of the results. Observation. }\end{array}$ & 3,9 \\
\hline Trainees' satisfaction & Analysis of the survey of the trainees. Interviewing. & 4,7 \\
\hline Attitude to the company & $\begin{array}{l}\text { Generalization of the data describing how the attitude of employees to the organization changed } \\
\text { after the training (if there is a greater understanding of the problems of organization, or if the loy- } \\
\text { alty to the enterprise increased). Indirect forms of assessment. Direct observation. }\end{array}$ & 4,6 \\
\hline
\end{tabular}

All the indicators justified the sufficient level of success in the implementation of the project of educational interaction of micro-enterprise employees in accordance with relevant conditions identified in the research. The analysis of experimental data confirmed the workability of the implemented model allowing the formation of general and professional competence in the trained workers. Experimental results confirmed the hypothesis that in case of working complex of organizational and pedagogical conditions, the educational interaction of micro-enterprise employees is effective (high and sufficient levels of the achieved result).

Discussions the specificity of the functioning of modern micro-enterprise (low budget, the wide range of functional responsibilities of employees, the pursuit of strategic and situational flexibility) in cludes vocational training in the context of solving specific practical problems. The historical models of educational and professional relations between a skilled worker and an inexperienced one were studied by Batyshev (1976). At the present stage of development of the society, these models are implemented ineffectively, since the change of socio-economic conditions broke the communications within these models. The pedagogical situation of teaching a potential employee by an experienced worker, using the internal resources of a micro-enterprise, requires understanding of existing approaches to the vocational training [22].

The second stage of the study coincided with the change in the global economic situation. On the one hand, the global financial downturn created additional complexities in carrying out the forming experiment in the conditions of a micro-enterprise. The preservation of jobs during this period was employers' first task. On the other hand, the downturn made the topic of research urgent: the redundant employees get involved into new professions; they need vocational training or additional training for their new jobs in micro-enterprises [23].

This research addressed the contradiction between the growing needs of the individual, the society and the economy in vocational training improvement in the conditions of micro-enterprises, and the opportunities of educational interaction of employees in the sport and recreation sector to satisfy these needs through on-the-job training. The teaching conditions which ensure efficiency of the pedagogical interaction were developed. The learning process is represented by an education project based on Bespalko's approach

\section{Conclusion}

On a theoretical level, the importance of this research is justified by the contribution to the development of professional pedagogy. The concept of educational and professional interaction of the employees was specified in the development and description of the education project for the sport and recreation micro-enterprises. The research results gave a more comprehensive approach to the problems of training and may serve as a basis for further research of theoretical bases for training micro-enterprises employees.

The practical significance of this study is confirmed by the implementation of research results in the organization of educational interaction of the sport and recreation micro-enterprise employees. The specified pedagogical conditions for educational and professional interaction of micro-enterprise employees ensure the efficiency of vocational on-the-job training.

The results are in demand in pedagogical community, as evidenced by the publication of the results in scientific journals, discussion of the main provisions of research at scientific conferences, and feedback from the trainees. They are also confirmed by the heads of micro-enterprises that have introduced the research results into the businesses practices.

\section{Recommendations}

This study does not pretend to be a comprehensive analysis of the studied problem. The research prospects lie in the fact that this topic provides many opportunities for further study. Learning the basics of pedagogical design in the preparation of bachelors is a prerequisite for further successful professional activity of graduates in the sport and recreation sector. 


\section{References}

[1] Babansky, Yu.K. (1982). V poiskakh optimalnogo varianta [Searching for an optimal variant]. Moscow: Pedagogika, $183 \mathrm{p}$.

[2] Kubrushko, P.F. (2001). Soderzhanie professionalno-pedagogicheskogo obrazovaniya [Subject matter of vocational pedagogical education]. Moscow: Vysshaya shkola, 236 p.

[3] Zagvyazinsky, V.I. (2008). Teoriya obucheniya: Sovremennaya interpretatsiya [Theory of education: modern interpretation]. Moscow: Academia, 192 p.

[4] Zeer, E.F. \& Pavlova, A.M. (2009). Subektivnye predposylki lichnostnoy avtonomii individualnykh predprinimateley [Subjective prerequisites of personal autonomy of individual entrepreneurs]. The Education and Science Journal, 10 (67), 40-48.

[5] Bespalko, V.P. (1994). Proektirovanie pedagogicheskikh system Proektirovanie v obrazovanii: problemy, poiski, resheniya. [Design of pedagogical systems. Project design in education: problems, studies, solutions]. Moscow, 198 p.

[6] Fedorov, V.A. \& Davydova, N.N. (2014). Control of the research and education network development in modern socio-pedagogical conditions. Naukovyi Visnyk Natsionalnoho Hirnychoho Universitetu, 2, 126-133.

[7] Fedorov, V.A. \& Komleva, S.V. (2015). Uchebno-professionalnoe vzaimodeystvie rabotnikov mikropredpriyatiya: otechestvennaya praktika i ee preobrazovanie $\mathrm{v}$ sovremennykh sotsialno-ekonomicheskikh usloviyakh [Educational and professional interaction of micro-enterprise employees: Russian practice and its transformation in modern socio-economic conditions]. Pedagogicheskiy Zhurnal Bashkortostana, 2 (57), 10-18.

[8] Zyryanova, N.I., Fedorov, V.A., Zaitseva, E.V., Tolkacheva, I.S. \& Glushchenko, P.S. (2016). Modern Requirements to Preparation of Professional and Pedagogical Personnel. International Journal of Environmental and Science Education, 11(16), 8800-8810.

[9] Andruhina, T.V., Dorozhkin, E.M., Zaitseva, E.V., Komleva, S.V. Sosnin, A.S.\& Savinova, V.A. (2016). Scientific-theoretical background the organization of geobotany employees of the micro enterprises in sport and recreation sector. International Journal of Environmental and Science Education, 11(17), 9773-9785.

[10] Komleva, S.V. (2011). Pedagogical conditions of the organization of vocational training of workers of small enterprise. The journal: Nauka i Studia, 13 (44), 58-62.

[11] Fedorov, V.A. \& Tretyakova, N.V. (2017). Vocational-pedagogical education in Russia: historical and logical periods. The Education and Science Journal, 3, 93-119. (In Russian) DOI: 10.17853/19945639-2017-3-93-119.

[12] Fedorov, V.A. \& Komleva, S.V. (2017). Professional training in the terms of microenterprises: process modelling of educational and professional interaction. The Education and Science Journal, 2, 124-144. (In Russian) DOI: 10.17853/1994-5639-2017-2-124-144.

[13] Knowles, M.S., Holton III, E.E. \& Swanson, R.A. (2005). The Adult Learner: The Definitive Classic in Adult Education and Human Resource Development.6th edition. London, New York, etc.: ELSEVIER Butterworth Heinemann, 378 p.

[14] Gavrilova, I.V. \& Zaprudnova, L.A. (2016). Formalnaya, neformalnaya $\mathrm{i}$ informalnaya modeli obucheniya [Formal, non-formal and informal learning models]. Molodoy uchenyy, 10 (114), 1204-1206.

[15] Romantsev, G.M., Fedorov, V.A., \& Mokronosov, A.G. (2012). Professionalnoe obrazovanie $\mathrm{v}$ sisteme obespecheniya moderniziruemoy ekonomiki rabochimi kadrami [Vocational education in the system of the modernized economy provision with staff]. Universitetskoe upravlenie:praktika i analiz, 6 (82), 6-13.

[16] Petryakov, P., Pevzner, M. \& Graumann, O. (2012). Korporativnaya pedagogika. Kontseptsiya i tekhnologii korporativnogo vospitaniya, obucheniya i obrazovatel'nogo menedzhmenta $\mathrm{v}$ organizatsiyakh [Corporate pedagogy. The concept of technology and corporate training, learning and educational management in organizations]. PalmariumAcademikPublishing. 372 p.

[17] Batyshev, S.Ya. (1976). Proizvodstvennaya pedagogika [Pedagogy in production]. Moscow: Mashinostroenie, $688 \mathrm{p}$.

[18] Kolesnikova, I.A. (2003).Osnovy andragogiki [Fundamentals of andragogy]. Moscow: Akademiya, $240 \mathrm{p}$

[19] Davydova, N.N., Dorozhkin, E.M. \& Fedorov, V.A. (2016). Innovative process development in the framework of scientific educational network: management model. Naukovyi Visnyk Natsionalnoho Hirnychoho Universitetu, 5, 157-163.

[20] Fedorov, V.A. \& Tretyakova, N.V. (2016). The Development of Vocational Pedagogical Education in Russia (Organizational and Pedagogical Aspect). International Journal of Environmental and Science Education, 11(17), 9803-9818.
[21] Khodayari Bavil, A., Razavi, S.E., on the thermo-flow behavior in a rectangular channel with skewed circular ribs, Mechanics \& Industry, 182 (2017) 225, https://doi.org/10.1051/meca/2016057.

[22] Kislov, A.G. (2014).Vocational masters training in the context of growing social and professional mobility. The Education and Science Journal, 7, 47-64. (In Russian) DOI: 10.17853/1994-56392014-7-47-64

[23] Dorozhkin Y.M. \& Shcherbina Y.Y. (2013). Development trends of vocational education in the context of socio-economic changes. The Education and Science Journal, 6, 65-74. (In Russian). DOI: 10.17853/1994-5639-2013-6-65-74. 